\title{
Globalization and Multiculturalism: Defining the New Universalism in Selected Texts of Samuel Selvon, V. S. Naipaul and Anita Desai
}

\begin{abstract}
By Sarah Anyang Agbor
Culture and ideology have blended together such that language traditions; imagery, myths and beliefs have been integrated into literary works. Cultural boundaries have been broken and borders have become elastic such that culture as a means of survival has become transnational and translational. Thus a hybrid culture has evolved and multiculturalism seems to have moved beyond the mere combination and cohabitation of different cultures to describe the growing phenomenon of cultural annihilation which results from the collision of cultures producing the first signs of a future universal culture. The birth of this universal culture passes inevitably through the ideological flux that characterizes this age of globalization. What are the social, political and economic implications of the elements of cultural plurality in a developing country? Is a nation a mere geographical expression? We argue that an outward-looking cultural identity-one that rejects the fixities of locality and embraces the fluidity of the universal-makes cultural diversity not only more acceptable but also desirable; in that cultural identity makes global polity more acceptable.
\end{abstract}

The cultural encounters that come with the phenomenon of globalisation seem to rebut the very meaning of multiculturalism hitherto understood banally "as the availability of different 'ethnic' foods, music, art and literature in the one society" (Milner \& Browitt, 2002, p.142). In other words, multiculturalism has often been read as synonymous with cultural plurality. However, migration and cultural dislocation encouraged by the growing trend of globalisation and transnationality portrayed in the postcolonial novel is producing another phenomenon that transcends cultural pluralism or multiculturalism. As described by Milner and Browitt, "multiculturalism was one of the central matters at issue in the American 'culture wars' of the 1990s" (ibid.). They argue that conservative critics of multicultural policies saw it as divisive:

...insofar as it focused on the needs and complaints of specific social groups defined by ethnicity or race. A threat to national stability and traditional values, [...] multiculturalism could even lead to the disuniting of America. At the other extreme, radical critics tended to see multiculturalism as a strategy of containment, accepting the need to recognize and foster the cultural diversity of a society, but within the pre-established and overarching institutions and values that traditionally harboured discriminatory and exploitative policies.

\footnotetext{
* Associate Professor, University of Yaounde 1, Inspector of Academic Affairs N0 1., Ministry of Higher Education, Yaounde, Cameroon.
} 
According to this argument, society and culture are irreparably marked by divisions of class, gender and race that are repressed by unitary conceptions of culture, even if these are ethnically multicultural. (Milner \& Browitt, 2002, p.143)

In contemporary postcolonial fiction, the above-mentioned divisions that accrue from multiculturalism do not exist. Rather, cultural encounters lead to cultural annihilation, cultural merging and cultural redefinition such that cultural specificities give way to cultural fluidity. This fluidity then becomes in itself the very expression of the global identity; that is an identity that is not 'located' in any definable geographical or cultural space. This perspective on globalisation is in line with Michel S. Laguerre's theory whereby he sees globalisation as the "transnational practices of immigrant communities , the flow of cultural notions, and global processes come together to create 'a new kind of citizen, the diasporic citizen, and to imagine some of the ramifications and consequences of this modus vivendi for the citizen-subject" (Chierici, 2004, p.44).

It is through this 'diasporic citizen' - their protagonists - that V.S. Naipaul, Samuel Selvon and Anita Desai portray the new universalism, the result of cultural rapprochement. The 'new universalism' as underscored in this paper is the universalism embodied in the experience of the diasporic citizen. The idea of universalism originating from the colonial discourse intended to spread European culture to the colonized world as the universal culture, thus annihilating colonial cultures. Doris Summer points out for instance that "universal rights is an idea that parts company with what Europeans had assumed to be a universal culture" (Summer, 2005, p.171). The new universalism as portrayed in the postcolonial novel is no longer the spread and imposition of a specific culture and cultural identity on others but the product of cultural mélange that defies any form of 'location'.

Doris Summer cites Ernesto Laclau who argues provocatively along with some critical legal scholars:

...that universalism is promising today because it depends on difference. It has survived classical philosophy's dismissal of particularity as deviation, and it has outlived a European Enlightenment that conflated the universal (subject, class, culture) with particular (French) incarnations. Today's universalism is a paradox for the past, because it is grounded in particularist demands. They unmoor universalism from any fixed cultural content and keep it open to an "always receding horizon." Precisely because citizens cannot presume to feel, or to think, or to perform alike, their ear for otherness makes justice possible. That is why political philosophy and ethics, from Benjamin and Arendt to Bakhtin and Levinas, caution against empathy, which plays treacherously in a subjectcentered key that overwhelms unfamiliar voices to repeat solitary sounds of the self. (Summer, 2005, p. 171) 
This means that the content of a universal culture is indefinite and indefinable; it is a permanent construction as seen in the lives of Willie, Arun and Moses and their struggle to integrate and assert themselves in other cultures. The transformations of self and host societies reflect the very meaning of globalization in the postcolonial world. As Rose-Marie Chierici observes, "In this "loosely bordered", globalized space, immigrant life may be interpreted in terms of continuity rather than disruption, and rerootedness rather than uprootedness [...] Immigration becomes an intrinsic mechanism in the structural deployment of the globalization process" (Chierici, 2004, p.45). Chierici's point seems to be that the globalisation process which dislocates and relocates the migrant subject in utter defiance of cultural and political-even racial and ethnic - boundaries is a natural one and nothing like the imperial design of colonialist 'universalism' that constructed colonial others and 'justified' their subjugation and domination by Europe.

Universalism is coming to signify the expansion of a third cultural space resulting from hybridisation and mutual cultural annihilation. Thus a hybrid culture has evolved and multiculturalism seems to have moved beyond the mere combination and cohabitation of different cultures to describe the growing phenomenon of cultural annihilation which results from the collision of cultures and which produces the first signs of a future universal culture. The birth of this universal culture passes inevitably through the ideological flux that characterizes this age of globalization. The notion of 'home', location and place as fixed and stable has been affected by globalisation as 'home is becoming ever more elusive and illusive as people have been 'liberated from "the confinements and ravages of imperialism" and the "settled, established, and domesticated dynamics of culture" (Strehle, 2008, p.145) the migrant has become the very incarnation of "unhoused, decentred, and exilic energies" (ibid.).

Willie Summerset Chandran in V.S. Naipaul's Half a Life personifies this universalization of culture (Naipaul, 2001). Born in a post-independence India, whose cultural identity has already been affected/infected by European incursion, Willie's own personal identity is hard to define. And this is a major problem to young Willie. It is so important that the first part of the novel is entirely devoted to tracing the origins of the 'strange' name. Through Willie, Naipaul paints the typical picture of the contemporary postcolonial subject. Willie's hybridity, seen first in his name and then in adult life, is in line with that which is described by Bart Moore-Gilbert in Postcolonial Theory Contexts, Practices:

...the best way forward now is a mode of cultural criticism which reflects, indeed espouses, the hybridity engendered by the ever more intertwined histories of the modern world, and which eschews conceptions of identity which are based in fixed ontological categories, whether of race, ethnicity or national identity. To anchor cultural projects in such models is ... to risk remaining for ever stuck in the posture of confrontation.

(Moore-Gilbert, 2005, p.64) 
We see this intertwining of histories in Half a Life through the colonial history whose effects on the colonial subject have come to constitute the latter's own history as well, such that in the modern world, Willie's history like Indian History would be incomplete without reference to European history of colonisation and vice-versa. Despite the strong presence of purely Indian cultural values (see the caste laws and gender issues), English education and way of life seem to have upset the tranquillity of that Indian cultural identity. Willie's father rebels against Indian cultural values and shows his preference for British culture by giving his son an English name. His disdain for such cultural values is seen in the fact that he marries a "backward", despite being himself a Brahmim. As he puts it: "My decision was to turn my back on all those ways of death, to trample on them, and to do the only noble thing that lay in my power, which was to marry the lowest person that I could find" (Naipaul, 2001, p.12). This rejection of cultural values is the beginning of a more encompassing rejection of the conception of identity based in what MooreGilbert calls "fixed ontological categories" (2005, p.64).

The cultural plurality of his post-independence Indian background thus has significant social, political, and economic implications on the identity of the migrant Willie. Born and raised in a caste-ridden Indian society, Willie's scholarship plunges him into a British society that defies cultural definition. Shortly after arriving in Britain, he realises that his acceptance and integration of British society will depend to a larger extent on his ability to shed some of his Indianness and embrace some Britishness. In other words, Willie comes to understand that self-definition in terms of a specific, located identity is not possible in a society that seems to disregard the values by which his 'place' and entire being have hitherto been defined. That is when he realises that he "could present himself as he wished, [...] that he could write his own revolution" he "begin[s] to re-make himself and his past and his ancestry" (Naipaul, 2001, p.57) by "playing with words" (ibid., p.58). The new self that Willie seeks to construct is that of the 'diasporic citizen', not located in any geopolitical space but rather belonging simply to the world. This is what Arun could not do in Fasting, Feasting.

Anita Desai's Fasting, Feasting (1999) embodies the dialectic of 'self/other' in its treatment of male/female relationships in India. Melanie, the rebellious and self-willed daughter of the Pattons is the antithesis of Uma, the unfortunate suppressed Indian girl. Uma, however, is conscious of her own worth and her desire to get educated despite her incapability, underscores Desai's feminist stance- that education is necessary for the woman's emancipation and liberation. Melanie has privileges that Uma is denied. Her second class status is emphasised in Mama's submission: "in my day, girls in the family were not given sweets, nuts, and good things to eat. If something special had been bought in the market like sweets or nuts, it was given to the boy in the family" (Desai, 1999, p.8). This sentence is made to abort Uma's desire for education. However, a new universalism can be seen through the American Melanie who is more privileged and enjoys more rights. Melanie gets the right to eat sweets and other delicacies which are forbidden from Uma. Desai reveals that: 
Melanie is eating the ice-cream. Her lips part so she can cram the spoon in, loaded and dripping onto her chin, then diving down for more and more of the sweet sticky dribbling stuff with which she needs to satisfy herself. (Desai, 1999, p.215)

In order for the Indian girl to enjoy similar advantages and privileges, some norms of that society have to be reviewed, reconsidered or simply eliminated. Uma's situation sharply contrasts Sarojini's in Naipaul's The Mimic Men (1969). Despite her 'backward' 'untouchable' status, she works her way out of Indian patriarchal darkness and redefines her 'self' in the Diaspora. By embracing the new universalism which involves the shedding of some of her Indianness that fails to correspond to her new-found selfhood, Sarojini becomes a citizen of the world and begins to see her world from a new perspective.

Desai juxtaposes her characters to show contrast between the Indian and American cultures. Each character in the Indian context can be compared and/or contrasted with another in the American context. Papa's authoritative and domineering attitude can be contrasted with Mr. Patton's liberal attitude; Mama's submissive, subservient and obedient attitude can be contrasted with Mrs. Patton's confident and self-assertive attitude. The latter is free to do whatever she wants. She goes out without her husband's consent and she owes no explanation to anyone, which is not the case with the former. If she wants to go out, she has to wait for her husband to decide when and how; otherwise, she stays home. If she is not with him, she cannot go out. "Papa gets into the front seat and waits for Uma and Mama to get in. He's taking them for an outing to the park" (Desai, 1999, p.11). It is also the case with Anamika whose plight Desai describes as follows:

When Anamika was not scrubbing or cooking she was in her motherin-law's room either massaging that lady's feet or folding and tidying her clothes. She never went out of the house except to the temple with other women. Anamika has never once been out alone with her husband. (Desai, 1999, p.71)

Patriarchal norms stifle the woman. Furthermore, American women engage in leisure activities as going to the beach in bathing suits which expose their bodies. Swimming pants and the beach are not strange in the American context as it is part of the culture and custom of the place. But in India, such habits would be considered deviant and inappropriate because they go against the culture and the customs of the place.

Arun goes to America to continue his education. It is not easy because he meets new realities which are different from what exists in India. Consequently, he has a problem of adaptation. At the Pattons' residence in America, Arun soon learns that he is in a completely different environment from his Indian background and soon enough, he has to learn to do some of the things he has been taught were reserved for women only; like cooking and 
other household chores. He finds himself in a new environment where, however hard he tries, it is difficult for him to confine himself to Indian values. Desai clearly points this out in the following excerpt from Fasting, Feasting:

It was the first time in his life away from home, away from MamaPapa, his sisters, the neighbourhood of old bungalows, dusty gardens and straggling ages where he had grown up, the only town he ever known; he had at last experienced the total freedom of anonymity, the total absence of relations, of demands, needs, requests, ties, responsibilities, commitments. He had no past, no family and no country. (Desai, 1999, p.172)

Like Ralph Singh, Arun is in the middle of nowhere, unanchored; a true diasporic citizen despite the ever present Indian background to which he unsuccessfully seeks to cling. It is not easy for Arun to live in America and succeed without embracing the new universalism. Finding that there is need for him to reject the stifling Indian values, he transgresses his Indian identity and assumes a translational, transnational identity. Arun's dream in the text is to get a room in which he can live in peace without disturbance. "His dream of a selfcontained room in an apartment or housing block where no one would know him or talk to him was disintegrating" (Desai, 1999, p.174). It seems that Desai equally seeks a new individualism that will allow a crossbreed of cultures even in the person of Arun and Uma.

In a thesis entitled "Identity, Discrimination and Violence in Bessie Head's Trilogy" Corwin Luthuli Mhlahlo (2002) argues that:

The exploration of identity offers a compelling display of the somewhat tortuous emergence of a critical and resistant selfconsciousness, which begins to question that which is fixed and given. [...] self-definition and indeed self-realisation become a process of growth, playing through, at times, the hybrid and the liminal towards a possibly more contented subjectivity. With the attainment of an at least provisionally re-constituted and chosen selfhood, myriad forms of violence previously experienced as a result of constructed otherness begin to dissipate. (Mhlahlo, 2002, pp.8-9)

While in Britain, Willie's otherness becomes irrelevant as his new self is not anchored to a specific cultural location. Unlike Arun in Desai's Fasting, Feasting who seeks to assert his Indianness by rejecting American food, Willie integrates the Bohemian society of London comprising people from various ethnic, racial, cultural and national backgrounds who live above all forms of prejudice. Their cultural backgrounds have receded in importance and relevance as they move out of divisive identity definitions to occupy Homi K. Bhabha's 'Third Space'. These characters, Mathews, Percy Cato and Willie Chandran have all come to Britain from postcolonial societies to confront the discourse that 'othered' them in the colonies. By migrating, they have been 
caught in that elusive realm that Wilson Harris calls 'a certain "void" (qtd in Moore-Gilbert, 2005, p.183). The idea of the 'void', Moore-Gilbert argues, "prevents the cultures or cultural forms which are being negotiated from ever reaching full equivalence or synthesis and therefore closure". In Harris's definition, the 'void' connotes that element which in Bhabha prevents full 'translation' (the concept of 'translation' is one which Harris also recurrently employs in discussing cross-cultural transactions).

Going by this conception of the 'void', we can read Willie's experience in London, Africa and continental Europe (Charlottenburg) as an example of Naipaul's portrayal of the impurity of cultural identity. "Spivak suggests that the idea of a 'pure' (and accessible) subaltern consciousness is a necessary 'theoretical fiction' which enables a critique of the dominant models of colonial and national-bourgeois historiography to be begun" (Moore-Gilbert, 2005, p.87). Willie's experiences in Half a Life are a confirmation of Spivak's analysis because through them, Naipaul demonstrates that the purity of cultural identity is indeed a "theoretical fiction". Fortunately for Willie, his life has been a permanent repudiation of cultural purity. His father's rejection of Indian "ways of death" in favour of an open-ended approach to cultural identity is a confirmation of the new universalism as expressed in the postcolonial novel.

Willie comes to Britain with high hopes and expectations, hopes and expectations born in him by his colonial background which constructed the grandeur of the coloniser in opposition to the lowness of the colonised. The polarity created by this colonial rhetoric is dissipated by globalisation through migration and the new universalism. This same hope and expectations push the Anglo Caribbean to England as exemplified in Selvon's trilogy: The Lonely Londoners, Moses Ascending and Moses Migrating.

Moses' years in Britain instil in him a new sense of universalism; thus, he sees himself redefined as an ambassador en route to Trinidad to sell the merits of the mother country- Britain. He says:

Out on deck, ere we left the English Channel, I had come to the conclusion as Brit' $n$ faded on the horizon that I would be a credit to the country, an ambassador not only of goodwill but good manners. The idea put a different complexion on my circumstances. (Selvon, 2008, p 48)

The new universalism also shows the relationship between globalisation and multiculturalism. Tolroy despite living in an individualistic society, remembers his responsibilities to his family. He saves money and brings his family to London. However, Moses instead cut off all links with his native country. He says "All this years in Brit'n I never wrote nobody: I didn't even know if she was alive or dead" (Selvon, 2008, p.40). It is only when he is thinking of returning home to Trinidad that he remembers Tanty Flora, who took him in as a child after his parents abandoned him in front of her doorsteps. For all the years in London, he has never once written to her nor even sent her money for sustenance. 
Significantly, as a migrant writer, Sam Selvon documents the experiences of the Caribbeans in the new 'motherland' of England through his protagonist Moses who himself has been a migrant for long and whose experiences parallel Selvon's own life. His trilogy could be read as an exploration into the process of cultural and identity redefinition in the context of globalization. While The Lonely Londoners (1956) portray the phenomenon of culture shock and the juxtaposition of colonial discourse and the 'reality' of the colonial world, Moses Ascending (1975) reflects the integration and 'decolonisation' of the colonial subject, leading inevitably to the construction and emergence of the universal/global citizen, which is the Moses that we find in Moses Migrating (2008).

How do the West Indians reconstruct and redefine their identity in the wake of all these challenges? The way out is a new universalism which gives them the opportunity to survive in the motherland. This is only achieved through transnational and translational identities which give birth to hybridised identities. Hybridity is a multicultural process. Hybridity is also perceived in the emotional consciousness of the immigrants. The following passage narrates some of the early experiences Moses had in the city:

When Moses did arrive fresh in London, he look around for a place where he wouldn't have to spend much money, where he could get plenty food, and where he could meet the boys and coast a old talk to pass the time away for this city powerfully lonely when you on your own. (Selvon, 1956, p.47)

As a result of the new universalism, Moses Aloetta adapts to life in London. While he remains isolated due to his race and national identity, Moses has learned the ropes of the city. Therefore he becomes the godfather to fellow migrants, friends and relatives who often go to him when they need assistance in establishing themselves in the city.

Lordes Lopez Ropero in "Diaspora: Concept, Context, and its Application in the Study of New Literatures", notes:

A migration tradition, therefore, started in the Caribbean after Emancipation and continued to the present in different configurations. Caribbean migration is, therefore, an institution, a rite of passage, a tradition rooted in a land made up of displaced people. The aftermath of the post-war migration from the British Caribbean was the dispersal of the Caribbean people throughout Europe and North America. The Caribbean 'nation' thus transcends its Caribbean boundaries, encroaching into a number of nation-states -England, US, Canada. (Ropero, 2003, p.19)

Significantly, if the "The Caribbean 'nation' thus transcends its Caribbean boundaries, encroaching into a number of nation-states -England, US, Canada" (Ropero, 2003, p.19), then they will experience a cultural fusion. No wonder then that the characters in Selvon's trilogy evolve and create new 
universalisms, because there is now a cultural merging between innate traditions of the original location (homeland) and the new location (host land/mother country).

One way that the characters embrace a new universalism is to introduce dance and calypso in London. Multiculturalism can be gleaned through popular music. Jennifer Rahim discusses the concept of calypso and the notion of belonging. In an article entitled "(Not) Knowing the Difference: Calypso Overseas and the Sound of Belonging in Selected Narratives of Migration" (2005), she reveals that calypso was a means through which the West Indians combat with the notion of belonging. In relation to the experience of the characters in Sam Selvon's novels, Rahim notes that:

Indeed, Selvon's narratives supply moving and humorous accounts of West Indians attempting to insert themselves in an unwelcoming British environment. The music is depicted as offering a means to more aggressively assert a collective, regional identity across ethnicities and nationalisms as a front against British discriminatory practices. Homesick and socially displaced West Indians in metropolitan London turn to calypso music for a much-needed sense of community. Cultural anchoring and connectivity become increasingly necessary as they confront the traumatic reality that their race and island origins take on greater or differently politicized meanings, which keep them on the margins of the British social order. (Rahim, 2005, p.5)

Through this music the characters are able to "assert a collective, regional identity" (ibid.). It is in this wise and in acknowledgement of this conflict that Amit Shankar Saha explains:

The effect that exile has, not on the writers' work, but on the writers themselves seems apparently paradoxical at first. Exile appears both as a liberating experience as well as a shocking experience. The paradox is apparent because it is just a manifestation of the tension that keeps the strings attached and taut between the writer's place of origin and the place of exile. Whatever may be the geographical location of the exiled writer, in the mental landscape the writer is forever enmeshed among the strings attached to poles that pull in opposite directions. (Saha, 2009, p.188)

The carnival is also one way of creolising British culture x-rayed in Selvon's trilogy. When the people were not allowed to celebrate the carnival during the Second World War, because the British high commissioner thought it will be callous for people in the Caribbean to enjoy while the mother country was at war, there was an uproar not only among the natives but also the Whites. The spirit of the carnival is strong as evident in the following: 
So we went chanting and prancing, the whole mob moving like one, but each individual doing his own thing. Some of them running ahead when the van take them to lead the band, and the true leaders don't mind, because every now and then somebody get the vap, and me and Doris do it too, shrieking and screaming like we gone mad. And in truth, I don't know come over me that morning, if memories of bygone Jouvert return after all my years in stuffy old Brit'n, or if it was that I was in the midst of my countrymen now, the pulse and the sweat and the smell and the hysterical excitement, but my head was giddy with a kind of irresistible exultation like I just get emancipated from slavery. (Selvon, 2008, p.180)

The spirit of the carnival is strong and makes people let go and actually enjoy themselves. Moses says in Moses Migrating (2008) that it is in the course of the dancing that memories of past carnivals come to mind. He reconnects with his roots as he says the jouvert has actually washed away all the memories of suffering in "stuffy old Brit'n". It is also at this moment that Moses appreciates the beauty of his culture and feels a sense of belonging with his countrymen.

Significantly, the jouvert carnival becomes a catharsis. The effect of the carnival on Moses is such that it releases Moses' pent up emotions such that he proposes to Doris:

Doris!' I scream, 'Doris-! Let we get married.' 'What you say?' What you saying, Moses? I can't hear you, man!' 'mas, mas, play mas!' 'Doris! Oh, God, Doris, is Jouvert morning!' 'it too sweet! Let we married, Doris, let we married! I don't going back. (Selvon, 2008, p.181)

Moses' bliss through this experience can be seen in the following confession:

When I look back on my life, I see many times when there was a climax to a certain chain of circumstances and events, when one would have gladly given up life. If one had the choice, would one opt for a demise in the past, or take pot-luck in the future? Imagine being asked by St Peter at the pearly gates, after he show you flashback, "That was your life, my son. When would you have preferred to die?" I would say, "you remember that Jouvert morning when I was with Doris in the hotel, St Peter? (Selvon, 2008, p.182)

Moses' role in the trilogy is multiple as he seems to have an understanding of everything that is going on in the society. The twenty years between the Moses we find in The Lonely Londoners and the one we find in Moses Migrating have equipped him with the experience that is necessary for survival. The new universal space that is needed for Moses' survival is echoed in Santiago's observation of Moses' hybrid identity in Moses Migrating: 
Moses in Moses Migrating has been transformed into a Caribbean/London hybrid. He has maintained his island culture and views and has creatively syncretized them with the cultural realities of the peripheral city life of the London immigrants; thus the cultural hybrid consists of "Caribbean Islands periphery" with "London periphery." The overlapping area from both these peripheries has produced new hybrid forms. What Moses and some of the immigrants have absorbed from the centre is only the "survival" culture... that was so important for their well-being in the metropole. The immigrants are not welcomed in the metropole, and they then strive to create a "colony" of people with similar attitudes and ideas. (Selvon, 2008, p.123)

Moses's hybridity results from the combination of his Caribbean values and the survival attitude that is typical of a metropolis like London. Although they are not welcome in the world of London, they strive and succeed to create a group of people with similar ideas.

This new universalism is also exhibited in a mélange of cultures and diversity in the Islands. Through globalisation and multiculturalism, Trinidad has engulfed a new universalism and evolved. In Moses Migrating, Moses is surprised to see these changes:

I look around the establishment. It wasn't like the kind of parlour I remember in the old days. It was all spick and span, a few people was sitting at tables, and it had some more girls behind the counter to serve customers, and a cash register machine. It even had machines dispensing the drinks she mentions. And no flies were buzzing around. (Selvon, 2008, p.102)

Moses contrasts the present establishment with the old snack places he used to know while growing up. This present establishment looks like a place where tourists will be comfortable in, just like Moses who seems to adore anything pretentiously British. He could not get a glass of Mauby and is laughed at by the Service as being primitive, and they would not even believe that he is from London. Moses still believes that:

Things are different in England, I stood my ground, thinking I might as well start to put the facts straight. I addressed them all. "In England, people are trustworthy. They leave their money on the pavement in full sight of the public and not a soul touches it. Do you mean to say that it have so many thieves coming in this parlor that you have to pay first before you eat or drink?" (Selvon, 2008, p.103)

The West Indian in the homeland has inculcated the new universalism through their contact with the imperial culture. Therefore they have become 
hybrids by inculcating aspects of Western culture as well as their traditional culture. So we see that culture as a means of survival must be 'transnational and translational' as Bhabha argues. Moreover, this melange of cultures also gives birth to mulattoes. The relationship between the whites and Caribbeans gives birth to neither whites nor blacks but mulatoes. Moses describes Doris thus:

I caught my breath as I did. I will say one thing for the potpourri mixtures of races that populate the islands, sometimes out of the brew you get a species call high-brown, and the females of that concoction is some of the most beautiful creatures in the world, a glorious composition of sperms and ovaries that create the best of the first, second and third world. Doris remind me of that saying, a thing of beauty is a joy forever. My heart was pounding as I wait to be formally introduced to her, but as this did not forthcome I step over a bale of velvet and push out my hand. (Selvon, 2008, pp.108-109)

The Caribbean is considered an exotic place of beauty and this is reflected in the aforementioned excerpt.

Multiculturalism and geographical and social landscapes bring out the complex nature of the Caribbean and the influence it has had in other areas of the world, like Britain, Africa, Asia and Europe. Their translational and transnational as well as multicultural experiences have emphasized a kind of cultural plurality as well as having given birth to a new universalism and hybridised identities. The multiple ways in which Naipual, Selvon and Desai have revealed Diaspora paradigms as evident in the lives of their characters cannot be overemphasized. The process through which Diaspora characters negotiate their identity and strike a compromise with the demands of living in the new host land as well as the struggle to retain the identity of the homeland, creates a new universalism.

\section{References}

Chierici, R.M., 2004. Caribbean Migration in the Age of Globalization: Transnationalism, Race, and Ethnic Identity. Reviews in Anthropology, Vol. 33, Taylor \& Francis Inc., pp.43-59.

Desai, A., 1999. Fasting, Feasting. London: Vintage Random House.

Laguerre, M.S., 1984. American Odyssey: Haitians in New York City. thaca, N.Y., and London: Cornell University Press.

Mhlahlo, C.L., 2002. Identity, Discrimination and Violence in Bessie Head's Trilogy. MA Thesis. University of South Africa, November, 2002.

Milner, A. \& Browitt, J., 2002. Contemporary Cultural Theory. New South Wales: Allen \& Unwin.

Moore-Gilbert, B., 2005. Spivak and Bhabha. In: H. Schwarz \& R. Sangeeta, eds. A Companion to Postcolonial Studies. Oxford, Blackwell, pp.451-466. 
Naipaul, V.S., 1969. The Mimic Men. Harmondsworth: Penguin.

Naipaul, V.S., 2001. Half a Life. New York: Vintage.

Rahim, J., 2005. (Not) Knowing the Difference: Calypso Overseas and the Sound of Belonging in Selected Narratives of Migration. Anthurium: A Caribbean Studies Journal, 3(2), Fall 2005. [Available from: www.anthurium.com, Accessed: March 2012].

Rohlehr, G., 2001. Calypso and Caribbean Identity. In: G. Glyne, ed. Bucknell Review: Caribbean Cultural Identities. London: Bucknell University Press, pp.55-72.

Ropero, L.L., 2003. Diaspora: Concept, Context, and its Application in the Study of New Literatures. Revista Alicantina de Es tudios Ingleses, 16, pp.6-30.

Saha, A.S., 2009. Exile, Literature and the Diasporic Indian Writer. Rupkatha: Journal of Interdisciplinary Studies in Humanities, 1(2), Autumn 2009. [Available from: www.rupkatha.com/journalvol1no2.php].

Selvon, S., 1956. The Lonely Londoners. BurntMill: Longman Group Ltd.

Selvon, S., 1975. Moses Ascending. London:Heinemann.

Selvon, S., 2008. Moses Migrating. Boulder: Reprint edition Lynne Rienner Publishers Inc.

Strehle, S., 2008. Looking for Home in the New World. Contemporary Literature, 49(1), Spring 2008, pp.145-150, University of Wisconsin Press.

Summer, D., 2005. A Vindication of Double Consciousness. In: H. Shwartz \& S. Ray, eds. A Companion to Postcolonial Studies. Malden: Blackwell Publishing, pp.165-179. 
